НАУКОВИЙ ВІСНИК

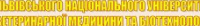

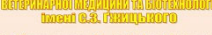

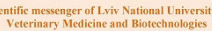

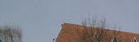
2. 11) MIIIII - Hides as if СЕРА: ХАРчОВ технологі Том 22 № 94 2020
Науковий вісник Дьвівського національного університету ветеринарної медицини та біотехнодогій імені С.3. Гжицького. Серія: Харчові технології

\section{Scientific Messenger of Lviv National University} of Veterinary Medicine and Biotechnologies.

Series: Food Technologies https://nvlvet.com.ua/index.php/food

UDC 628.1.663.6

\title{
Research of regularities of formation of health-improving antioxidant electron-donor properties of functional drinking water modified with ascorbic and citric acids
}

\author{
Y. Bolshak, O. Kalenyk, A. Marynin, R. Svyatnenko \\ National University of Food Technologies, Kyiv, Ukraine
}

Article info

Received 27.08.2020 Received in revised form 28.09.2020 Accepted 29.09.2020

National University of Food Technologies, Volodymyrska Str., 68 Kyiv, 01601, Ukraine. Tel: +38 (044) 289-95-55 E-mail:Svyatnenko@i.ua
Bolshak, Y., Kalenyk, O., Marynin, A., \& Svyatnenko, R. (2020). Research of regularities of formation of health-improving antioxidant electron-donor properties of functional drinking water modified with ascorbic and citric acids. Scientific Messenger of Lviv National University of Veterinary Medicine and Biotechnologies. Series: Food Technologies, 22(94), 3-7. doi: $10.32718 /$ nvlvet-f9401

Drinking water is a food of special physiological value, as evidenced by a critically short for health and life endurance of complete dehydration of the body (no replenishment of drinking water) in 9-10 days along with 45-49 days of life without food. However, even without extreme circumstances, without any shortage of drinking water and food, the quality of the latter has a serious impact on human health. For some time, as environmental pollution increased, the efforts of hygienists were aimed at ensuring the safety of drinking water through its appropriate physical and chemical treatment. Then came the realization that the microbiological and chemical safety of drinking water does not guarantee its inherent in the best samples of natural water physiological value. The meaning of this newly introduced into the normative circulation of the concept is the awareness of the importance of water as a source of replenishment of the body physiologically necessary for normal life minerals and trace elements. Subsequently, nutrients were synthesized that are produced by the body itself and the normal content of which in cells is critical for life. Natural sources of replenishment of the body with nutrients (good food and especially vegetables, berries, fruits, etc.) for various reasons are not always available to many people, so specially prepared drinking (functional) water has gained in recent years growing popularity and high health value. The presented results of research of functional water on the basis of ascorbic and citric acid are our contribution to the development of methods of health nutrition. The influence of functional water with acquired antioxidant properties on the human body is substantiated. The developed water provides drinking water with a pleasant harmonious taste, which has a tonic and healing effect, increasing the body's resistance to fatigue and stress. The development relates to the field of production of soft drinks, in particular drinking water.

Key words: Functional drinking water, biological activity, antioxidant properties, biological activity, nutrients, ascorbic and citric acid, health effects of drinking water.

\section{Дослідження закономірностей формування оздоровчих антиоксидантних електронодонорних властивостей функціональної питної води, модифікованої аскорбіновою та лимонною кислотою}

\author{
Ю. В. Большак, О. С. Каленик, А. І. Маринін, Р. С. Святненко
}

Національний університет харчових технологій, м. Київ, Украӥна

\footnotetext{
Питна вода є продуктом харчування особливої фізіологічної иінності, про щчо свідчить критично короткий для здоров'я $і$ життя термін витривалості повного зневоднення організму (відсутності поповнення його питною водою) - 9-10 діб поряд з 4549 добами життя без продуктів харчування. Але й без екстремальних обставин без жодного дефіциту питної води і продуктів доброякісність останньої серйозно впливає на показники здоров'я людини. Певний час в міру зростаючого забруднення довкілля
} 
зусилля гігієністів були спрямовані на те, шьоб домогтися безпеки питної води шляхом ї̈ відповідної фізико-хімічної обробки. Далі прийшло розуміння того, щзо мікробіологічна та хімічна безпека вжсвання питної води не гарантує їй притаманної кращим зразкам природної води фізіологічної повночінності. Сенсом цього нововведеного в нормативний обіг поняття є усвідомлення важливості води як джерела поповнення організму фізіологічно необхідними для нормальної життєдіяльності мінералами та мікроелементами. Згодом було синтезовано біогенні речовини, котрі виробляються самим організмом і нормальний вміст яких в клітинах критично важливий для життя. Природні джерела поповнення організму біогенними речовинами (доброякісні продукти харчування і насамперед овочі, ягоди, фрукти, тощо) з різних причин не завжди доступні багатьом людям, тому спеціально підготовлена питна (функиіональна) вода набула останніми роками зростаючої популярності та високої оздоровчої иінності. Подані результати досліджень функиіональної води на основі аскорбінової та лимонної кислоти є нашим внеском в розвиток методів оздоровчого харчування. Обтрунтовано вплив функиіональної води з надбаними антиоксидантними властивостями на організм людини. Розроблена вода забезпечує отримання питної води з приємним гармонійним смаком, щзо володіє загальнозміцнюючою і оздоровчою дією, підвищення стійкості організму до перевтоми і стресів. Розробка належить до галузі виробництва безалкогольних напоїв, зокрема питної води.

Ключові слова: функиіональна питна вода, біологічна активність, антиоксидантні властивості, біологічна активність, біогенні речовини, аскорбінова та лимонна кислота, оздоровчий вплив питної води.

\section{Вступ}

Вода є дуже чутливою стосовно зовнішнього фізичного впливу на неї. Вона здатна сприймати цей вплив, накопичувати енергію, змінюючи структуру та інформаційні фактори зовнішнього впливу й передавати набуті структурно-енергетичні та інформаційні фактори тим системам, які призначені природою для ïх сприйняття (Ukrainets et al., 2018).

На сьогодні базовим біохімічним процесом, що забезпечує нормальну життєдіяльність організму та регулює енергетичні потреби на підтримку гомеостазу та метаболічні процеси в клітинах, є підтримка належної швидкості окисно-відновних реакцій, яка залежить від концентрацій і співвідношення окислених та відновлених форм речовин в організмі людини, тобто підтримка окисно-відновного гомеостазу водних біосередовищ організму. Їх окисно-відновний потенціал визначає активність іонів та характеризує відхилення балансу іонної та електронної компоненти внутрішньоклітинних середовищ. Окрім цього, окисно-відновний потенціал характеризує біологічну активність рідинного середовища, яка впливає на біологічні системи та дозволяє оцінити ефективність біоенергетичних процесів. При цьому зростанню величини окисно-відновного потенціалу зі знаком плюс відповідає пониженню активності електронів в розчині, а зростанню величини ОВП зі знаком мінус - збільшення активності електронів, що супроводжується формуванням відновного стану водного середовища (Ukrainets et al., 2019).

Фізіологічну повноцінність питної води можливо отримувати шляхом надання їй фізіологічно оптимального окисно-відновного балансу. Проте існують численні методи та прилади для біоактивації питної води. Як відомо, окисно-відновний потенціал характеризує рівень активності електронів у окисновідновних реакціях, пов'язаних 3 приєднанням або передачею електронів.

Кількісно стан окисно-відновної рівноваги оцінюється величиною окисно-відновного потенціалу. Кров i зовнішньо- та внутрішньоклітинне середовище перебуває у відновному електронодонорному стані 3 величиною ОВП мінус 100-200 мВ і з слаболужною реакцією. В кислому середовищі шлункового соку ОВП досягає величин кількох сотен мілівольт зі знаком плюс (Ukrainets et al., 2018; Bolshak et al., 2019).
Ринок ізотоніків і функціональних напоїв в Україні ще на ранньому етапі свого розвитку. Більшість цієї продукції імпортного походження. Знецінення національної валюти призвело до зростання вартості напоїв і скорочення продажів. Так, в 2017 році обсяг цього ринку зменшився на 7 \%. Водночас той самий валютний фактор сприяв збільшенню вітчизняного виробництва функціональних напоїв. Він росте, починаючи з 2016 року, і за рахунок цього за підсумками 7 місяців 2018-го зафіксовано збільшення обсягу ринку таких напоїв на 8 \% порівняно з аналогічним періодом попереднього року (Zavhorodnia, 2009).

Першими функціональними напоями можна вважати низькокалорійні дієтичні напої, що з'явилися ще в середині XX сторіччя, в яких натуральні підсолоджувачі, такі як цукор, були замінені штучними. В 1960 роках з'явився новий клас напоїв - “спортивні”, які не містять газу, натомість насичені вітамінами або іншими речовинами, вони покликані підвищувати витривалість спортсменів, ефективно втамовувати спрагу. 3 того часу виробництво функціональних напоїв розвивалося дуже швидко, значно розширюючи асортимент та цільове призначення. Внаслідок багаторічної роботи над розробкою різних видів функціональних продуктів сучасні напої, крім свого традиційного складу, збагачені екстрактами лікарських рослин, плодів та коренів, вітамінами та іншими біологічно активними речовинами. Тому функціональні напої сьогодні - це не просто засіб втамувати спрагу, а також можливість надати організму додаткових сил, поліпшити його адаптаційні та імунні властивості та забезпечити захист від порушень у роботі певних органів чи систем (Zubkova et al., 2012; Khakhalieva, 2017).

Вільні радикали являють собою сполуки, які позбавлені на зовнішніх електронних орбіталях одного або більше електронів. Молекула, маючи непарний електрон, з легкістю вступає в хімічні реакції. Однак хімічні реакції, викликані вільними радикалами, мають побічні негативні наслідки для організму. Потрапивши в клітини людини, вільні радикали забирають електрони 3 довколишніх структур, спричиняючи окисні руйнації ліпідних прошарків клітинних мембран та інших структур (Henyk, 2016).

У нормі невелика кількість вільних радикалів присутні в людському організмі й виконують відведену ім фізіологічну роль. Імунна система антиоксидантно- 
го захисту контролює їх діяльність і регулює їхній вміст. Якщо кількість вільних радикалів понаднормово зростає, можливий ланцюговий процес їх неконтрольованого синтезу. В результаті змінюється структура білків, процеси кодування генетичної інформації і передачі їі від клітини до клітини. Патологічно змінені білки розпізнаються імунною системою людини як чужорідний матеріал, вона намагається їх знищити. Таке навантаження часом не витримує система антиоксидантного захисту - імунітет падає, і можуть розвиватися важкі патології: рак, лейкемія, серцева, ниркова та печінкова недостатність (Wilson et al., 2017; Veurink et al., 2020).

Для протидії вільним радикалам є надійний спосіб - це надходження в організм антиоксидантів ззовні. Ці сполуки віддають окисленим молекулам свої електрони, відновлюючи їх до початкового природного стану, не втрачаючи при цьому своєї стабільності та активності. Припиняється негативний процес окисного руйнування молекул, руйнування клітин, створюється система протидії реакція окислення. Антиоксиданти теж стають вільними радикалами, але вони не мають майже ніякої окислюючої сили і не здатні руйнувати клітини (Franco \& Martínez-Pinilla, 2017).

Антиоксиданти - це речовини, які нейтралізують вільні радикали. Внаслідок дії антиоксидантів уповільнюється старіння людського організму. Чим вищий вміст в організмі антиоксидантів, тим вища тривалість життя. Спостереження за мишами, в організмі яких стимулювалося посилене вироблення антиоксидантних ферментів, дозволило виявити збільшення тривалості їхнього життя на $20 \%$.

Якщо перенести ці показники на людину, то тривалість життя таких людей повинна становити від 100 років і більше. Американські вчені з університету Вашингтона підтверджують гіпотезу щодо того, що вільні радикали провокують посилене старіння організму. В організм людини антиоксиданти надходять 3 рослинною їжею, вітамінами, амінокислотами. Частина антиоксидантів утворюються в організмі людини (ферменти, гормон мелатонін).

Найдоступніші антиоксиданти: альфа-ліпоєва кислота; вітаміни А, Е, С і бета-каротин; цинк; флавоноїди; глутатіон (даний антиоксидант виробляється самим організмом); гінкго білоба.

Щоб протистояти вільним радикалам, потрібно застосовувати нескладні заходи: включати в свій раціон достатню кількість овочів і фруктів, уникати ультрафіолетового опромінення, приймати вітамінні та мінеральні комплекси.

Метою роботи є розробка на основі теоретичних та експериментальних досліджень функціональної питної води зі зміненим показником ОВП в бік відновного електронодонорного стану питної води.

\section{Матеріал і методи досліджень}

Як об'єкт використовували дистильовану воду. Для регулювання показника $\mathrm{pH}$ використовували розчини хлоридної кислоти та натрій гідроксиду. Окисно-відновний потенціал вимірювали потенціоме- трично 3 платиновим індикаторним електродом та стандартним хлоросрібним електродом порівняння.

\section{Результати та обговорення}

Аскорбінова кислота та іï натрієва (аскорбат натрію), кальцієва і калійна солі застосовуються в харчовій промисловості як антиоксиданти Е300-E305, продукти, що запобігають окисненню. Їхня біологічна роль - утворення колагену, серотоніну з триптофану, катехоламінів, синтез кортикостероїдів; аскорбінова кислота також бере участь в перетворенні холестерину на жовчні кислоти; відновлює убіхінон і вітамін Е; стимулює синтез інтерферону, отже, бере участь в імуномодулюванні; переводить тривалентне Залізо в двовалентне, тим самим сприяє його всмоктуванню; гальмує глікозування гемоглобіну i перетворення глюкози на сорбіт.

Лимонна кислота $є$ проміжним продуктом метаболічного циклу трикарбонових кислот, що відіграють важливу роль в системі біохімічних реакцій клітинного дихання. Антитоксичну дію лимонної кислоти обумовлено здатністю до нейтралізації важких металів (Свинцю, Кадмію) за допомогою утворення з ними важко-всмоктуваних комплексів.

Результати експериментальних досліджень показано на рис. 1-3.

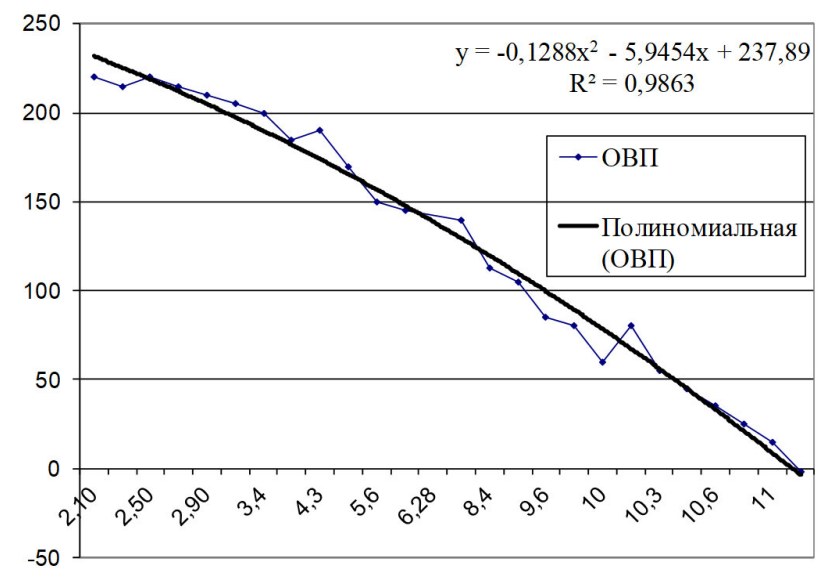

Рис. 1. Залежність ОВП дистильованої води від $\mathrm{pH}$

За результатами експериментальних досліджень підтверджено, що введення лужного реагенту забезпечує очікуване підвищення $\mathrm{pH}$ води та зростання величини ОВП зі знаком мінус. При зміщенні величини $\mathrm{pH}$ до значень, більших за 11, досягаються від'ємні значення ОВП. Водночас $\mathrm{pH}$ води відповідно до ДСанПіН 2.2.4-171-10 має становити 6,5-8,5. Тому виникає необхідність пошуку прийнятних способів досягнення від'ємного показника ОВП зі збереженням нормативного кислотно-лужного балансу води.

Аналіз динаміки зміни ОВП та рН при збільшенні концентрацій лимонної та аскорбінової кислот (рис. 2 та 3) показує тенденцію збільшення ОВП у разі застосування лимонної кислоти і зменшення у випадку аскорбінової кислоти, що добре корелюється з відомими антиоксидантними властивостями аскорбінової кислоти. 


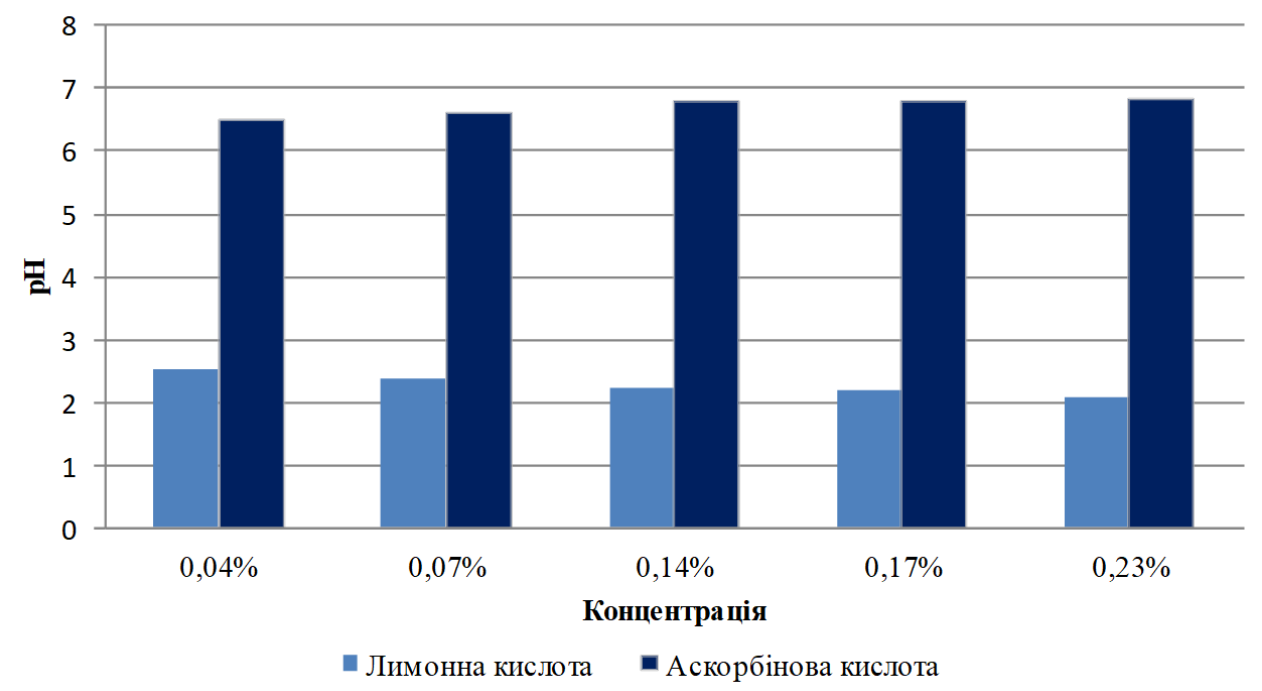

Рис. 2. Динаміка зміни рН аскорбінової та лимонної кислоти

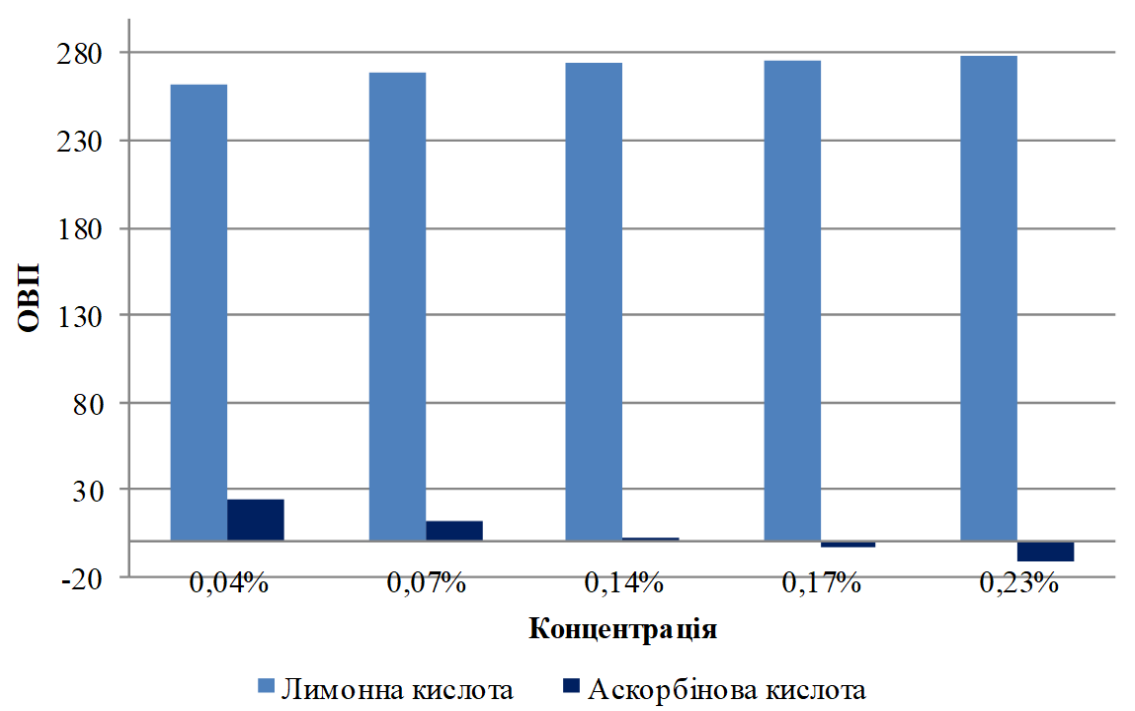

Рис. 3. Динаміка зміни ОВП аскорбінової та лимонної кислоти

3 діаграми на рис. 2 можна зробити висновок, що показники $\mathrm{pH}$ води у разі застосування аскорбінової кислоти перебувають у межах 6,5-6,82, що відповідає нормам відповідно до ДСанПіН 2.2.4-171-10. У разі використання розчину лимонної кислоти $\mathrm{pH}$ води не відповідає нормативним вимогам.

3 діаграми на рис. 3 видно, що відновних властивостей, тобто від'ємних показників ОВП, набула вода з вмістом аскорбінової кислоти. Так, за концентрацій аскорбінової кислоти 0,04-0,23 ОВП води було в межах $+25-(-11)$.

\section{Висновки}

Отже, аналіз результатів показав, що ефективний результат зниження ОВП досягається у разі використання аскорбінової кислоти.

Таким чином, від такої обробки вода набуває відновних властивостей, а $\mathrm{pH}$ аскорбінової кислоти збільшується, що не характерно для кислот. Проте аскорбінова кислота, що $є$ антиоксидантом, надає водним розчинам електронодонорний стан, якому притаманна слабо лужна реакція.

За результатами проведених досліджень підтверджено набуття розчином аскорбінової кислоти відновного редокс-стану з прийнятною для вживання такої води кислотно-лужною рівновагою. При введенні аскорбінової кислоти у кількості $0,04-0,23 \%$ розчин набуває від'ємного значення ОВП.

Перспективи подальших досліджень полягають у встановленні впливу тривалості процесу на зміни ОВП у зразках води з різними концентраціями аскорбінової кислоти.

\section{References}

Bolshak, Yu. V., Ukrainets, A. I., Marynin, A. I., \& Sviatnenko, R. S. (2019). Vyvchennia vplyvu KVChoprominennia vody na yii strukturno-enerhetychnyi stan i mozhlyvi biolohichni naslidky protsesu. Naukovi pratsi Natsionalnoho universytetu kharchovykh tekhnolohii, 
25(5), 216-225. URL: http://dspace.nuft.edu.ua/ jspui/handle/123456789/30615 (in Ukrainian).

Franco, R., \& Martínez-Pinilla, E. (2017). Chemical rules on the assessment of antioxidant potential in food and food additives aimed at reducing oxidative stress and neurodegeneration. Food chemistry, 235, 318-323. doi: 10.1016/j.foodchem.2017.05.040.

Henyk, S. M. (2016). Vilni radykaly: rizna rol pry riznykh obstavynakh. Arkhiv klinichnoi medytsyny, 2, 9-10 (in Ukrainian).

Khakhalieva, I. (2017). Rynkovi perspektyvy fiziolohichno funktsionalnykh napoiv. Tovary i rynky, 2(2), 104116 (in Ukrainian).

Ukrainets, A. I., Bolshak, Yu. V., Marynin, A. I., \& Sviatnenko, R. S. (2018). Okysno-vidnovnyi balans pytnoi vody-pokaznyk yii yakosti ta fiziolohichnoi povnotsinnosti. Kharchova promyslovist, (24), 6-14. URL: http://dspace.nuft.edu.ua/jspui/handle/123456789/3004 2 (in Ukrainian).

Ukrainets, A. I., Bolshak, Yu. V., Sviatnenko, R. S., \& Prokhorenko, Zh. I. (2018). Zastosuvannia fizychno zminenoi (aktyvovanoi) vody dlia pidvyshchennia efektyvnosti tekhnolohii kharchovoho vyrobnytstva ta polipshennia yakosti produktsii. Naukovi pratsi Natsionalnoho universytetu kharchovykh tekhnolohii, 24(5), 218-224. URL: http://dspace.nuft.edu.ua/jspui/handle/123456789/ 30040 (in Ukrainian).
Ukrainets, A. I., Bolshak, Yu. V., Marynin, A. I., Sviatnenko, R. S., \& Pozniakovskyi, S. V. (2019). Teoretykoempirychna otsinka zmin strukturnoenerhetychnoho stanu fizychno zminenoi vody ta yikh biolohichnykh naslidkiv. Prohresyvni tekhnika ta tekhnolohii kharchovykh vyrobnytstv restorannoho hospodarstva i torhivli, 1(29), 172-184. URL: http://elib.hduht.edu.ua/ jspui/handle/123456789/4324 (in Ukrainian).

Veurink, G., Perry, G., \& Singh, S. K. (2020). Role of antioxidants and a nutrient rich diet in Alzheimers disease. Open Biology, 10(6), 200084. doi: 10.1098/rsob.200084.

Wilson, D. W., Nash, P., Buttar, H. S., Griffiths, K., Singh, R., De Meester, F., \& Takahashi, T. (2017). The role of food antioxidants, benefits of functional foods, and influence of feeding habits on the health of the older person: an overview. Antioxidants, 6(4), 81. doi: 10.3390/antiox6040081.

Zavhorodnia, V. M. (2009). Funktsionalni napoi spriamovanoi dii na osnovi naturalnoi syrovyny. Visnyk Lvivskoi komertsiinoi akademii. Seriia tovaroznavcha, 11, 30-34 (in Ukrainian).

Zubkova, K. V., Lihanenko, M. H., \& Kuznetsova, K. D. (2012). Funktsionalni napoi v kontseptsii zdorovoho kharchuvannia. Kharchova nauka i tekhnolohiia, 3, 25-27 (in Ukrainian). 